\title{
MAINSTREAM INDIAN MEDIA AND NAGA AUDIENCE: REPRESENTATION AND PERCEPTION
}

\author{
JASMINE YIMCHUNGER
}

Assistant Professor, Department of Mass Communication, Sikkim University, Sikkim, India

\begin{abstract}
This article is about the politics of television audiences. It is about Naganess as well. How do identities and subjecthoods such as Naga and Television get negotiated with regard to representation? The Indo-Naga political issue forms the wider backdrop to this study and this is explained in the article. This issue has intensified an awareness of deep differences and has emphasised the tensions between the local and national identities. The article through a focus group discussion with eleven groups in different parts of the Indian state of Nagaland sheds light on media representation as perceived by the Naga youth. Their responses challenge established national and cultural boundaries as well as identities. As the Indian state aims towards cultural homogenisation, the youth resist and negotiate such tendencies and recreate their own culture deftly nestled between tradition and modernity, centre and periphery.

KEYWORDS: Indo-Naga, Mainstream Indian Media, Nagaland, Representation, Minority, Audience \& Focus Groups
\end{abstract}

Received: Jan 16, 2019; Accepted: Feb 06, 2019; Published: Feb 21, 2019; Paper Id.: IJCMSAPR20193

\section{INTRODUCTION}

Indian media have seen a striking transformation since the economic liberalization of 1990s. However, the relationship between Indian media and its more than 100 ethnic minority groups is under-researched. Indo- Naga political imbroglio which is one of Asia's oldest unresolved issues has been dragging on for decades touching all aspects of the Naga society- political, social, and economic. In a politically sensitive region where issues of identity are at the forefront, how do the youth reconcile their culture and what is represented on Television? This essay addresses this question and by providing a historical context of the Indo-Naga political situation examines the reaction or the testimonies of the Nagas to the portrayals on Indian mainstream media. By examining how audiences negotiate with media content, we can better understand the degree to which Indian media depicts or disregards complexity in its representations of the Nagas and the meanings audiences make out of these representations. Instead of taking for granted the theories constructed by the state and the media, which project hegemonic narratives, a critical understanding of audience perspectives, can yield significant insights. A cursory look at the emergence of a unified Naga identity in opposition to India in the early $20^{\text {th }}$ century to date will help us in establishing the intricate relationship that this issue has on the engagement of Naga youth with television and how the two cannot be understood in isolation.

\section{HISTORICAL CONTEXT OF NAGA POLITICAL ISSUE}

The Naga political issue predates Indian Independence and it is today considered to be the longest unresolved political conflict in Asia. Commenting on the Naga political issue which has been able to sustain its movement for so many decades, unlike the ones in other Northeastern region, Phanjoubam (2015) says that the 
vital difference between the Naga movement and the others in states like Manipur, Mizoram, Assam and others is because the latter was more of a periphery striking back but in the case of the Naga, it launched itself on the grounds that they saw themselves as fundamentally different from 'mainlands'. The Naga rebellion unlike the other similar insurrections spawned in the region, in the decades after Indian independence, cannot be, for this reason, just a question of the periphery striking back and instead, is more like the periphery seeing itself as fundamentally different (Phanjoubam, 2015). Because of the ceasefire, conflict is in abeyance but the undercurrents of antagonism are far from resolved.

During British rule in India, the tribal areas were declared as 'excluded', 'partially excluded' and 'unadministered'. In the case of the Naga Hills, it became a separate district under the Raj in 1881, and from 1935 to 1947 , they were administered as an "excluded area". After India gained independence from the British in 1947 and in the wake of the partition of the British India into India and Pakistan, the Indian nationalist elite, took over political power from the colonisers. The post-colonial Indian state as part of its mission to build a strong and stable nation sought to integrate even the backward tribal communities living in the so-called 'excluded', 'partially excluded' areas of British India in the Indian Union. The 'unadministered' areas were also not left out in the process.

'Many Nagas, Mizos, and Manipuris, and even Assamese, do not consider themselves Indians, and it is necessary to understand why they feel that way' (Lintner, 2015: 3). When the Simon Commission visited India in 1929, the Naga Club $^{1}$ submitted a memorandum to the Commission expressing their desire for self-rule and not to be included in the Indian Union. The Nagas believed that the Indian state would be adversarial to the social values, customs, values, identities and the indigenous political structure of Naga society and so wanted to have a self-governing state separate from the Indian state. Since then, by invoking the right to self-determination on the basis of their 'unique' history and 'distinct' ethnic identity, the Nagas have been resisting the idea of the Indian state and thus providing a counter narrative. This resistance continues to this day, although there have been changes in the self-determination discourse. The ongoing Indo-Naga political issue is one of the world's longest-running ethnic insurgencies causing heavy casualties on both sides for decades (Lintner, 2015)

Prior to India's independence on 15 August 1947, the Nagas also declared their independence on 14 August 1947 from the British (Iralu, 2014). Comprising 16, 527 square kilometres, Nagaland was annexed to the Indian Union on 1 December 1963 and accounts for 0.17 percent of India's total population. With the redrawing of the map, the Nagas were scattered in the states of Assam, Manipur, Arunachal Pradesh and neighbouring country, Myanmar. The demand for unification of all the Naga-inhabited areas under a single administered state, either 'autonomous or independent' is the bone of contention in the Northeast of India (Choube 1985: 163 cited in Ranganathan and Rodrigues, 2010). The Nationalist Socialist Council of NagalimIsak-Muivah or NSCN-IM is at the forefront of demanding Greater Nagaland based on the claim that the Nagas were, prior to the annexation of India, a territory under British governance. The demand for a union of all the Naga inhabited areas surrounding the present State of Nagaland under the Indian Union, has largely been ignored by the powers that be as well as the mainstream media (Bezboruah 2006: 91; Hazarika 2006: 357). Statehood within the framework of India's Constitution has been unacceptable to the leaders and the founding fathers of the NSCN-IM, Thuingaleng Muivah and Isak Chishi Swu. It is argued by many researchers that the Naga middle class drew

${ }^{1}$ During World War I, about 4, 000 Nagas were sent to France by the British. In their contact with the outside world, the Nagas became aware of their own ethnic, linguistic, social, and cultural uniqueness. On returning, they formed the Naga Club in 1918 at Kohima. 
inspiration from the colonial theories that asserted that the tribals of Northeast India were racially, linguistically, culturally, politically, and economically distinct from the Indians (Pandey, 2011). The Naga nationalists initially wanted the issue to be settled in a democratic and peaceful way, but with the increase in the state's recourse to coercion and repression where destruction of homes and lives were carried out under the sanction, protection and legal immunity of Acts and Regulations like The Assam maintenance of Public Order Act, 1953; The Assam Disturbed Area Act, 1953; and The Armed Forces Special Powers Act, 1958, the Nagas gradually took to arms to fight and resist the state machinery.

The Indian political leaders were convinced that the Naga revolt would be contained by counterinsurgency strategy and that the Nagas would accept India's sovereignty in due course of time like it happened to other communities in the Northeast region. But it was not to be. The Naga struggle raged for decades, thus forcing the Indian government to adopt a major policy-shift towards the Naga movement in 1990s and made several attempts to negotiate peace with the insurgent groups. It negotiated cease-fire agreements with Isak-Muivah (IM) faction of the National Socialist Council of Nagalim (NSCN-IM) in the year 1997 and later with a Khaplang faction of the NSCN (NSCN-K) in 2001.

On August 3, 2015 a framework agreement (peace accord) was signed between the Centre and the NSCN-IM (National Socialist Council of Nagaland- Isak-Muivah). Much has changed in the Naga nationalist demand since the 1951 Naga referendum where $99 \%$ of the Nagas voted against being part of the Indian Union and establish a separate independent state (Yonuo, 1974: 202). Although the contents of the framework agreement has not been divulged, there is speculation that the demand for a sovereign Naga nation appears to have narrowed down to the demand of an autonomous, unified homeland within the republic of India. In early 2016, newspapers were rife with speculations that the Nagas would be granted a separate passport and national flag, but the speculation was laid to rest when the Government responded by saying there was no such formal declaration by the centre. (Baruah, 2016). Also, there are worries among the Naga civil society, whether the pact will include all components of public or will be the agenda of just a few people at the helm and if such an agreement can bring lasting and enduring peace.

With Indo-Naga political conflict which is one of Asia's oldest unresolved issues dragging on for decades, the youth in Nagaland are at a crossroad negotiating two identities- one of being a Naga and the other, being an Indian. Against the backdrop of the long standing Indo-Naga political imbroglio, issues of representation of ethnic minorities on mainstream Indian media and the ways in which Naga youth negotiate and contest these representations are analysed in the following sections.

\section{METHOD}

This article through a qualitative investigation employing ethnographic methodology explores the question of how the media consumers negotiate their multiple identities in their engagement with television by situating them within a socio-politico-cultural framework. It is based on data collected from eleven focus groups with Naga youth in urban and rural areas in three districts of Nagaland. Focus group was found to be a suitable method of inquiry given its "interviewing flexibility and insights regarding group dynamics" (Brennen, 2013, p. 59).

\section{PARTICIPANTS}

Eleven groups were identified under different categories for FGDs. The different categories included Students' union leaders, faculty members of colleges and university, NGO, Rock band, theatre group, church youth association and educated unemployed youth. 
There were about five-seven members in each group. Altogether there were 62 people, 19 female and 43 male. Before the FGDs and interviews, I distributed questionnaires to the participants to obtain general information like age, educational qualification, and occupation and also the channels and programmes of preferences. Each FGD lasted for anywhere between two to five hours.

The author was the moderator of all the discussions. The discussions started with refreshments and the discussions lasted anywhere between two to four hours. Informants were assured anonymity and with their permission the discussions were audio recorded.

\section{DISCUSSIONS}

\section{Media Representation and Audience Resistance}

The role of the mass media in the society is debatable. Politics of images are a site of contestation and struggle since communication is linked with power. 'Representation' is a complex concept, but for the purpose of the research, I restrict to the standard meaning of 'representation'. Representation means that something is/was already there or present and through the media, that something is re-presented (Hall, 1977). In other words, representation means standing in for something. The other idea of representation is whether the depiction of something is acceptable to the society that is represented.

There is a gap of communication between the shared meanings of the Nagas (explained in the following section) and how it is being represented by the media and it is this gap that the essay attempts to address. While it is argued in many studies that adopts the interpretative paradigm that there is no fixed meaning of anything in the first place, I shall not get into that discourse because there are some agreed upon codes of the Nagas and which the Naga society prefers to accept as the true or preferred meaning; otherwise, there would be no framework of collective intelligibility to make meaning out of anything. These shared codes and concepts which are arrived at through a 'process of naturalizing a subset of differences' are internalised and mobilized by the members of the society to articulate group identity (Appadurai, 1996: 15). What are the shared conceptual maps of the Nagas? It is difficult to map what constitutes Naga culture, but the categories that were once fluid and negotiable have been crystallized to become Naga culture. Drawing from different Naga scholars, I attempt to give a workable understanding of what Naga culture is although it is not an objective and standardized definition since there are always shifts in culture and their meanings over time. The Naga collective identity includes both material and immaterial ideas and values: a past that has often been painted by the British officers and administrators as proud warriors and headhunters, of their feasts of merit and their cycles of rituals, autonomous village republics in the past, familiar origin and migration myths. Many scholars who have embarked on research on the Nagas make it a point to mention that there are so many Naga tribes and each tribe's language is intelligible to each other and so there cannot be a common Naga identity because of this linguistic diversity. Responding to this, Abraham Lotha maintains that underneath the diversity of different tribes, there are underlying cultural essentials that unite the Nagas as one people (Lotha, 2013).

Jacobs (1990) points out that the Nagas' belief in fertility "is a central element in the cosmology which unites the diverse Naga communities" (1990: 117). Jacobs also points out other markers such as ornaments, cloth designs, and symbols that are commonly shared by all the tribes. When it comes to the socio-political and cultural aspects, Ao (2005) draws out many factors that are common to the Nagas such as feelings of Nagaism, village democratic principles, and self-rule village administration (pp. 24-30). Sema (1992); Venuh (2004, 2005) delineate the uniqueness of Naga polity as different from Indian polity and the role colonization played in restructuring it to its current form. The traditional Naga 
polity was village-centric and the system of administration varied from village to village and was either autocratic or democratic in nature. Giving an account of Naga polity, Elwin wrote, "Each village amongst the Ao (Nagas) is a small republic...it would be hard to find anywhere else more thoroughly democratic communities" (1969:324). This form of governance is claimed to be one of the basis on which Naga nationalists organised themselves to their right to selfdetermination as a people.

Chasie (2005) lays out five values to which Nagas "owe our very souls". According to him, the words, kenyu (taboo), mhoso (integrity, honour), menga (shame), terhomia(supernatural), peyu (wisdom) ${ }^{2}$ are values which shape the psyche of all the Nagas (2005: 121-123). Other markers are clan system, morung ${ }^{3}$, headhunting, Feast of Merit, Naga nationalism. All of these markers have been mobilized by the Naga nationalists and this consciousness of a people as a nation was concretized by the formation of the Naga Club in 1918, the memorandum to the Simon Commission in 1929 , the declaration of Naga Independence on August 14, 1947, the refusal to join the Indian Union in 1950, the Plebiscite on May 16, 1951, and the boycotting of Indian elections in 1952.

Also the spread and the embracing of Christianity has been instrumental in the creation of a joint, pan-tribal Naga identity. Tales of migration, myths of origin and memories have also contributed in the cultural construction of nationalism.

All of the above ethno-historical and socio-cultural reasons are invoked by Nagas to augment the argument that the Nagas belong to one society. Although there is a sheer range of differences and variations in the social and cultural fabric of the Nagas, Hodson (1911:19) warns that it should not permit us to lose sight of the 'essential unities underlying this wealth of variety'. Kaiser (2008) marvels that for all the formal diversity, the textiles made by various Naga groups; the wood carvings on house entrances and particularly on the morungs; and the songs are all highly developed art form specific to the Nagas and can be immediately recognizable as 'Naga' (p. 235). These cultural categories and criteria assigned both from within and without are now being consciously mobilized for identity politics, an 'us' and 'them' identity claims. This categorization is termed as 'instrumental conception of ethnicity’ (Appadurai, 1996:14) as opposed to the primordial idea of ethnic identity. Overtime, this instrumentation becomes so concretized that it slides into a primordial form and occasionally spills into xenophobia and all kinds of ethnic conflicts. Naga nationalism has been drawing on these differences and struggling for stronger recognition from the nation-state and to achieve its goal of pan-Naga identity that transcends the existing nation-states. Thus, the form of Naga identity that has been formed is of an ethnic and national character. This type of collective identity is best described by Weber as: "Human groups that entertain a subjective belief in their common descent because of similarities of physical type or of customs or of both, or because of memories of colonization or migration" (Weber, 1997: 18).

Nagas as a people has been written about by colonial administrators and ethnographers in the form of military reports, description of cultural practices and monographs and these writings have informed scholars, administrators,

\footnotetext{
${ }^{2}$ All these local words are in Angami language. Angamis are one of the Naga tribes. In Nagaland, the name of the tribe and the language spoken by the people belonging to that tribe bear the same name. In the last couple of decades, an effort has been made to develop a standardized Angami language along with a few other languages collectively called Tenyidie. ${ }^{3}$ Morung was a dormitory for the young people in the Naga traditional society. It was a tradition for all the boys after attaining puberty to live in the Morung for a certain period of time to learn the skills and crafts of community life. It was called by different names in different tribes and the customs varied from tribe to tribe and within the tribe, different villages had their own variations.
} 
missionaries and the public. With the coming of electronic media, Nagas as a people and their way of life got circulated through images. The images are powerful and they have a lasting impression on people's minds. Although the media is not the only means by which meaning is circulated in the society, it is one of the most powerful platforms of circulation of meanings; more so in our media-saturated world. The circulation of meanings almost immediately brings forth the question of power: 'who has the power in what channels to circulate which meaning to who?' (Hall, 2005) ${ }^{4}$. Power can never be subtracted from the question of representation. From the analysis of the responses of the participants, it is felt that Nagas as a group of people like many other minority groups are misrepresented, underrepresented or are glaringly absent from the media. The representation is mostly misinformed and selective. The coverage of the Dimapurlynching in the mainstream media is one clear example of the media representation and reinforcing the stereotypes of the Nagas as "savages" like it was rampant in the anthropological writings during the colonial times.

British writings on Nagas by military personnel, administrators, anthropologists and missionaries, mostly portrayed them as exotic, wild, savage, ignorant, stubborn and hostile to British interest. Lotha (2007) places the development of Naga ethnography under three broad chronological phases: Military (1832-1866), Political Control (1866-1877), Administrative (1878-1947). Some monographs include T.C. Hodson's Naga Tribes of Manipur (1911), J.P. Mills's The Lotha Nagas (1922), The Ao Nagas (1926c), and The Rengma Nagas (1937); J.H. Hutton's The Angami Nagas (1921a), and The Sema Nagas (1921b), Christoph von Fürer-Haimendorf's The Naked Nagas (1939); Henry Balfour's manuscript Diary of a tour in the Naga Hills (1922-23).

For the purpose of providing a representation work of the colonial era on the Nagas, I will cite a few examples from the chronicles that typified and stereotyped the Nagas according to their worldview. In one of his writings, Haimendorf writes that "I would soon be among real "savages" (Haimendorf, 1939:2). It is also said of the Nagas that "war is normal; peace is abnormal" (Mills, 1988: 71). Another English officer wrote, "They are the wildest and most barbarous of hill tribes, and looked upon with dread and horror by neighbours of the plains who consider them as ruthless robbers and murderers" (McCosh 1837: 136). Since the Nagas had no written history, this kind of writing by 'others' set the tone for the historical identity of the Nagas and irrespective of their reliability or not, post-colonial writings about the Nagas have been replicated, after the colonial writers had left, both by the Naga and non-Naga scholars. Terms like "headhunters" have become synonymous with the Nagas and due to a lack of work revising this kind of exaggerated representation, the colonial portrayal is being sustained to describe the contemporary Nagas. These writings by both colonial and post-colonial writers have shaped the understanding of the Nagas and the labels hold to this day.

No critical questioning is conducted on the colonial writings and it is only recently that critics have started to question the methodologies, point out the biases in the construction and reclaim Naga identity by demythologizing colonial portraits about the Nagas. A Naga scholar in attempting to revise the descriptive Euro-American writings, especially on the oft-used description of the Nagas as 'headhunters' says that "by using appalling and malevolent terminology, this cultural trait of the past was misrepresented and given a dreadful meaning which efficaciously stereotyped the colonized as more barbaric and violent than they actually were" (Thong, 2012: 385). Although a few corrective work has begun in the study on the Nagas, not much headway has been achieved and the trend of stereotyping the Nagas as though they were frozen in time based on the earlier writings abound both in print and electronic media.

\footnotetext{
${ }^{4}$ Transcript of a lecture titled "Representation and the Media" delivered by Stuart Hall and reproduced by Media Education Foundation in 2005 for educational and non-profit use by the public.
} 
Stereotype fixes the meanings that are given to groups. It is a form of colonialism. When we look at the representation of the Nagas on mainstream media, stereotypes are aplenty as we shall see in later sections. These stereotypical representations flame ethnic consciousness and in the process nationalistic aspirations only intensify. "Nagas by blood", a slogan which has been raised time and again in Nagaland where ideas of collective identity based on shared claims to blood, soil, memory and now religion, gets ignited. And the idea of Naganess as a unique, homogenous form of cultural difference gets further entrenched and the stakes associated with such identities become enormously high.

Communication is always linked with power to those groups who wield power in a society. Instead of just accepting representation of images at face-value, it is important to interrogate the representation and doing that unravels a lot of complex issues of power. When we are immersed in a flood of images, we might just come to accept them as part of the natural world. Television becomes like an extension of the human consciousness (McLuhan, 1964) and we don't question the extension, but if we step outside of it, then it is made up of a complex web of many factors, power being one of them. When certain ideological assumptions begin to saturate everyday discourse, they become common sense and the status quo prevails. We need to critically examine these images and the ideologies behind their portrayals and representation.

As Hall (1977) explains, representation starts right from the encoding process, when it is being produced and unless the encoders/ producers have a deep knowledge of the social, cultural, political, religious worldviews and the background of a particular group of people, then the gap between the encoded and decoded meaning will never be bridged and stereotypes will only be reinforced. Several textual and discourse analysis of minority representation on television (Sen, 2011; Mehta, 2008) have argued that mainstream Indian television portray and position the minorities stereotypically and negatively. These studies have found a pattern of bias in the representation of ethnic minorities. The biases are evident in the lack of background information and broad generalizations, negative stereotyping, ignoring historical context, and so on. To challenge this, these gaps will have to be contested, interrogated, debated and discussed.

Although meaning is contextual and shifts and is not fixed, identity constructions are extremely difficult to be wiped out once carved and often gets etched in the imaginations of the viewer and the everyday is viewed from the lens of the media constructions in reality as well, thereby, fixing meanings. This fixation of meanings closes, naturalizes and hides the complex processes of representations. And it is an ideology that is deeply implicated in those various processes. The construction is taking place outside of the dialogical spaces inhabited by the Nagas. The limited images of the Nagas effect how others perceive the Nagas in the real world and often it can have ominous implications. And in a profit-oriented market, the denaturalizing process will hardly be done by the producers to whom TRP (Television rating point) matters the most and Nagaland does not even come under the TRP towns.

A sense of being fairly represented and portrayed in the media may lead to minorities feeling a sense of belonging and inclusion. Along this line, Husband (2000) emphasizes the role of the media in creating a multi-ethnic public sphere, where diverse groups can feel they are making a contribution.

For more than four decades, the relation between the media and ethnic minorities, and the role of the media in a multicultural society have become areas of interests for academics, media producers and policy makers. The representation of ethnic minorities in the media, how they use media, and their degree of participation in media production, are all deemed to be indicators of social participation and integration. Media can play an important role in creating a feeling of 'belonging', a feeling of being included, of being part of society. 


\section{Contextual Disconnect and One-Sided Communication)}

The relationship of the mass media to power in society; how control is exercised over the media; and the nature of the power exerted by the media are recurring themes in many academic studies (Curran, 2002). Media owners can manipulate content and reproduce the relations of the dominant class. The dominant class maintains its power through control of ideas and culture. Although there are a number of channels to choose from, certain groups of people don't feel a sense of belonging and don't enjoy greater freedom of choice. One of the reasons why Indian television does not represent Northeast could be because the cities and towns of the region do not come under TRP (Television Rating Points) sample towns. Audiences therefore are numerically insignificant against the huge viewership in major Indian cities to which sponsorship is wedded (Hasan, 2004). In such a setting, audiences in such places receive what they get, even if they themselves are not visible in the images they consume. Television fails to reflect India's cultural diversity as an interviewee succinctly points out,

...in a place like Tuensang where we don't have access to such, you know, options, television becomes the only option and so it's a very dicey position but we're left with no option, so you know some of the debates which are happening on the television, on issues, and you really don't have a choice because they decide what themes to be because every channel has their own interest, they also have their own political leanings... (Personal interview, Tuensang).

The issue is not just one of non-representation, but also about the cultural disconnect one feels because of different cultural, religious backgrounds and these further increase the feeling of alienation.

But then the whole concept of honour killing is not explained through the media; it's only when you go to people, speak to them and they tell you the context of the Northern India where honour killings are very common thing, right across India, Northern India, even up to Pakistan and things like that...(Talwar case) (Personal interview)

With no context provided which is endemic to most television programming, audiences are left to their own devices to 'rewrite' the stories. The quote above also points to a reciprocal stereotyping of the 'other'. With no cultural proximity and the media lacking contextual information of an event/ phenomenon, the stereotyping on both sides is perpetuated.

\section{Stereotyping and Its Ills}

Violence and insurgency in the Northeast figure predominantly on mainstream Indian media and these frequent portrayals get absorbed in the minds of the viewers. Visual media serve an impetus to people's perceptions leading people outside the region to write off Northeast as a violent and unsafe region. Stereotyping can have serious ramifications to a people because it has the potential to colonize the mind (Fanon, 1963). According to Fanon, colonizing of the mind is "the emptying of the native's brain of all form and content", which "by a kind of perverted logic...turns to the past of the oppressed people, and distorts, disfigures, and destroys it" (p. 210). Following in the footsteps of the Euro-American colonial writers, the Nagas have also self-primitivized themselves and there is an abundance of such self-primitivization in both secular and ecclesiastic writings thus sustaining and perpetuating the colonial depiction. As the quote below shows, perceptions of minorities, other ethnic groups and societal groups, such as women, gays, and the elderly are largely formed from the media. The media also serve an educational platform for people who have little or no direct contact with members 
of the groups being treated.

I was studying in Bihar in 2005 and that time I came to know that many people don't know who the Nagas are. When I go out, people would shout out 'Nepali, Nepali' to them maybe because of the similarity in appearance. When I tell them that I am a Naga, they would ask me, "yein naga kya hai? (What is this Naga)" They don't know us because of no exposure and so they don't come here and show us on TV and so it's the responsibility of the politicians to see to it that people know Nagaland...We are all Indians although we have different religions, customs and culture. (Participant, Focus Group Discussion, Tuensang)

Boxed in by stereotypes, the depictions of the Nagas have been questionable in nature. Talking about the development of different art forms in India and the same being denied to the Naga people and their culture because of retrospect representation, an interviewee retorts:

Why should we be represented and reflected as museum pieces, naked people for all times to come. If you talk about the dances of India, you talk about Kathakali, you talk about kathak or Bharatnatyam, you talk about anything under the sun in the Indian dances, do you think that the Indian civilization just came about in that form? No. Over the years, it evolved and as it evolved, it changed. And as it changed it became more refined. (Personal interview, Kohima)

The philosopher, Charles Taylor, held the view that identity and recognition are related.

Our identity is partly shaped by recognition or its absence, often by the misrecognition of others, and so a person or group of people can suffer real damage, real distortion, if the people or society around them mirror back to them a confining or demeaning or contemptible picture of themselves. Non-recognition or misrecognition can inflict harm, can be a form of oppression, imprisoning someone in a false, distorted, and reduced mode of being (1994: 25).

Stereotypes assigned to a people can have serious ramifications reducing people to mere artefacts and such fixities in representations can have subtle and lasting manifestations in the minds of the people which are not easily removable. The implicit attitudes cultivated out of negative portrayals of a people can sometimes turn into explicit attitudes and deep-seated emotional antipathies toward minority groups (Gawronski and Bodenhausen, 2006).

The projection of the Nagas as "savages", "uncivilised" in many anthropological writings (discussed earlier) during the colonial times is reinforced again, but this time in the post-colonial writings using the same framework. Some of the responses below attest to it:

I was not happy with the 'Last Man Standing' on the Semas because it only showed the barbaric side of my people and we were shown as people cutting heads 50-60 years back. They just stayed in one village among the thousands of villages and only the primitive aspect was shown. (Participant, Focus Group Discussion, Kohima)

Media really influences others, they change the mind-set. So, instead of showing all the conflicts, the happenings that are going in Nagaland, those anti-social things, it's just 10\%-20\% of the happenings and the media projects just this. So, if they project all those things, the culture, cuisine, attires, lifestyle, 
tourism, they can display all those things though media, then I believe, you know, that will really change the mind-set of others also. (Participant, Focus Group Discussion, Kohima)

People in different regions have different versions of the single Naga story received from popular culture and this is a reinforcement of colonial anthropological writings. Anthropological accounts by the west began the tradition of telling Naga stories in the west, for the west, a tradition of narrativizing Nagaland as a place of negatives. And many people have bought those stories and it continues in the independent, post-colonial times as well. Single stories create stereotypes and the problem with stereotypes is not that they are not true but that they are incomplete. They make one story become the only story. As such, this is one kind of colonialism as Thong aptly remarks, "Colonialism, whether past or present, thrives on inventing mythological narratives and stereotypical images of the colonized" (Thong, 2013: 389).

\section{A Forgotten Frontier}

The stereotypes are reinforced even in the 21 st century. In all these years of conflict, allegations of neglect and deaths due to the violence, media representations revealed a range of attitudes toward the Northeast and Nagaland. From the extreme indifference of the mainstream media, which makes this region invisible to the world, to the extreme bias of the regional media, which supports resistance movements, and to journalists being killed, the Northeast has witnessed various swings of the media's attention. In all these, one overriding sentiment remains, that of neglect of the region by the mainstream media. It is absent in the Indian consciousness. It is an accepted framework in media coverage and does not raise eyebrows. The skewed coverage has become part and parcel of mainstream Indian media.

Many youngsters in this study felt that Northeast is treated more like a colony and not as one of the other states of independent India, with its own issues, identities, and cultures. So deep-rooted is this split that news reports from the region that find a space in mainstream media almost appear like concessions or charity being doled out to the region and its people. This creates a feeling of frustration in most viewers as is expressed by this respondent,

People don't recognize us and we have no option but to watch foreign channels. We don't like watching Indian channels because most of the programmes are in Hindi. (Participant, Focus Group Discussion, Tuensang)

When Northeasterners are seen in the media, more often than not, it's around sports, entertainment or crime, which feeds into the time-honoured tradition of negative stereotypes.

As far as the projection is concerned, it is mostly Hindu-centric. I don't watch TV much but whenever I watch, I always see the Tikka serials, you know the ones which are Hindu-centric because the Indian culture revolves around religion and as far as north-east is concerned, our projection is only when there is war and when there is anything negative, the positive side of our culture is not projected on the national TV channels. (Participant, Focus Group Discussion, Kohima)

What we see here is a deep feeling of dissatisfaction among ethnic minority groups about the media portrayal of them and reaction to the biased nature of television programming. Television privileges a particular cultural community and the smaller ones remain invisible in the bargain. These expressions point to notions of exclusion and non- or misrepresentation. Having the feeling of being given a fair share of treatment reflecting the ground reality without prejudices or at least having the feeling of being represented, helps to create a sense of belonging, or what Tufte (2001) and Appadurai (1996) calls 'locality', feeling at home somewhere. 
Many of the participants were of the opinion that a lack of knowledge about Naga culture is one of the main reasons behind the prejudices that the Nagas encounter and to curb that mainstream Indian television should include multicultural programmes so that people from other regions can be informed about the Naga culture and this will help in dispelling misconceptions about the Naga way of life and their culture.

People have got all kinds of wrong idea about the Nagas and their culture and tradition. They think Nagas are headhunters...Some even fear to visit Nagaland because of all these ideas. Programmes should not just focus on our past and the insurgency but also how we live everyday. There is so much to say about our culture (Participant, Focus Group Discussion,,Kuthur Village).

Harping on the past history of the Nagas as headhunters is a common theme in most of the documentaries on Nagaland screened on both national and international channels and this was resented by many of the participants. A complex practice by the Nagas like headhunting in the past is still portrayed and narrated in such a way as though it still were the order of the day. They feel the need for other aspects of the Nagas to be represented and not the same stereotypes being portrayed time and again. The participants reiterated that the region becomes visible only when there is conflict and the region becomes a spectacle and a theatre of conflict for viewers from other regions.

This feeling of exclusion and invisibility only strengthens their sense of alienation from the mainstream and further diminishes any sense of belonging. The absence of Naga characters in fiction series, soaps, talk-shows, game-shows, or other entertainment genres shows the neglect meted out to smaller audiences in the fringes of the nation-state and little effort is being made to show the multi-cultural, pluralism of the nation and cater to the diversity of the audience. The media tries to homogenize diversity, and diversity within and between the numerous different ethnic communities is ignored. This idea was reflected in many responses when they expressed their displeasure at the representation of the Nagas on Indian mainstream media. An interviewee opines,

National channels don't really cover Northeast or for that matter Nagaland well. We only get snippets like 'NSCN's Muivah has come', 'He has gone'. Interestingly, it's channels like BBC which carries the Naga issue. Infact, when they cover even the Naga issue, they actually visit the NSCN's camp in Nagaland and not just report from there....I remember seeing very solid work on Naga history and things like that...as for the national channels, they only show the mainland culture and I think they are influencing us more because of this one-way exchange...their culture reaches us and the reverse is hardly there...that's the saddest thing. (Personal interview, Tuensang).

His views suggest that a form of internal imperialism exists in India, where only the dominant culture is passed off as the national culture and lives and people in the fringes do not interest the television producers at the centre. Some perceive 'globalisation as an opportunity for change, while others see it as having a fractious effect on local cultures by creating new global communities with common interests' (French and Richards in Held 2000: 10). The excerpt conveys a sense in an increasingly global world, whichever part of the world we live in, our everyday lives are shaped by decisions and events over which we have little control. There is no denying that Naga society is changing politically, socially and culturally and 'media is but a sub-net in this process' (Giddens 2002: 10). However, as French and Richards notes, there is also a fear among the Nagas that their culture is on the verge of extinction because of all the global cultural forces and this was expressed by many of the research participants. 
When we look at Nagaland, we see that the youth are fast catching up with globalisation, but at the same time, we also see that there is a nostalgic revival of ethnic identities which is manifested in various Naga discourses. This resurgence might not lead to an epochal change as is assumed by many media imperialism and cultural synchronisation theories but we definitely cannot dismiss the sway media imperialism has as well. Although many channels are creating more regional or locally adapted versions in the form of dubbing its messages to local needs and culture; an example, in India being the bilingual idiosyncrasies of MTV (Pavarala, 1999), this trend doesn't take into account the numerous languages and dialects of the ethnic communities and so such approaches still remain foreign to them in the same country.

\section{CONCLUSIONS}

For cultures like Naga society where the ethno-linguistic cultural identity is more important than the national one, it becomes difficult to expect allegiance to the nation overnight because the allegiance even among the Nagas for all the talk about 'Naga identity' still lies with the tribe, village and clan.

The myth of "cultural backwardness" assumption where the Third World peoples were talked about as culturally retarded in their attitudes, customs, and technical abilities goes back to centuries of colonization and is reinforced today. Without romanticizing indigenous societies, we can say that they were culturally or socially no less inferior.

Instead of questioning the colonial disjuncture where mosaic cultures were made into monolithic culture, the decolonized nation is doing the same thing internally, attempting at ideological coherence. If, therefore, a communicator is to be understood by the audience, s/he will have to start by employing definers of broader frames of reference and then proceed to demonstrate a concern for the characteristics that define narrower frames of reference such as the personal interests and needs of the receivers. Often, the communicators designate their own frame of reference, thus mechanizing communication. In the process, a monologue and not dialogue define communication.

\section{REFERENCES}

1. Ao, L.(2005).Uniqueness of Naga History: A sociological debate. Mokokchung: Concerned Senior Citizens Forum.

2. Appadurai, A. (1996).Modernity at large: Cultural dimensions in Globalization. London: University of Minnesota Press.

3. Arsenault, A. H. \& Castells, M. (2008). The structure and dynamics of Global multi-media business networks. International Journal of Communication, 2 (2008), 707-748.

4. Balfour, H. (1922-23). Dairy of a Tour in the Naga Hills, Manuscript.

5. Baruah, S. K (2016, January 30). Nagaland may get separate flag as part of final accord with jCentre. Hindustan Times. Retrieved from http://www.hindustantimes.com/india/nagaland-may-get-separate-flag-as-part-of-final-accord-withcentre/story-gtaBiSGy262efMkz4qToaI.html

6. Bezboruah, D. N. (2006). India's forgotten corner. In: A. Mathur (Ed.),The Indian media illusion, delusion and reality essays in honour of Prem Bhatia (pp.86-97).New Delhi: Rupa\& Co,

7. Brennen, B. (2013). Qualitative research methods for media studies. New York, NY: Routledge.

8. Chasie, C. (2005). Nagaland in transition. India International Centre Quarterly, 32 (2/3), 253-264.

9. Curran, J. (2002). Media and power. London: Routledge.

10. Elwin, V. (1969). The Nagas in the nineteenth century. Bombay and London: Oxford University Press. 
11. Fanon, F. (1963). The wretched of the earth. New York: Grove Press.

12. Furer-Haimendorf, C. V. (1939). The Naked Nagas: Head hunters of Assam in Peace and War. London: Metheun\& Co. Ltd.

13. Gawronski, B., \&Bodenhausen, V. (2006). Associative and propositional processes in evaluation: An integrative review of implicit and explicit attitude change. Psychological Bulletin, 132, 692-731.

14. Giddens, A. (2002). Runaway world. London: Profile Books.

15. Hall, S. (Ed.). (1977). The work of representations. In Representation: cultural representations and signifying practices (pp.15-74). London: Sage and the Open University.

16. Hasan, D. (2004) Out of the Box: Televisual Representation of North-East India. Sarai Reader 04: Crisis/Media, 126-129.

17. Hazarika, S. (2006). Terrorism and sub-alternity - III: India and the sub-nationalist movements in Mizoram and Nagaland. InImtiaz Ahmad (Ed.), Understanding terrorism in South Asia: beyond statist discourse(pp. 345-370). New Delhi: Manohar Publishers and Distributors.

18. Held, D. (2004). A globalising world? Culture, Economics, Politics. London: Routledge.

19. Hnamte, L., \& Pachuau, Z. Computational study of concerted reaction pathways for $N$-alkylanine transformation to aniline in acid media and under gas phase.

20. Hodson, T. C. (1911).The Naga Tribes of Manipur. London: Macmillan \& Co. Ltd.

21. Husband, C. (2000). Media and the public sphere in multi-ethnic societies. In Cottle, S. (Ed.),Ethnic minorities and the media (pp199-214). Buckingham: Open University Press.

22. Hutton, J. H. (1921). The AngamiNagas. London: Macmillan.

23. Hutton, J. H. (1921). The SemaNagas. London: Macmillan.

24. Iralu, K. (2014). Uncovering the political lies that have covered Indo-Naga history from the 1940's to the present.Kohima: Kaka. D. Iralu.

25. Jacobs, J. (1990). The Nagas: Hill Peoples of Northeast India: Society, Culture and the Colonial Encounter. London: Thames and Hudson.

26. Kaiser, T. (2008). The songs of the Nagas. In M. Oppitz, T. Kaiser, A. von Stockhausen, \& M. Wettstein (Eds) Naga Identities: Changing Local Cultures in the Northeast of India (pp.47-56). Gent: Snoeck Publishers.

27. Lintner, B. (2015). Great Game East: India, China, and the Struggle for Asia's Most Volatile Frontier. New Haven and London: Yale University Press.

28. Lotha, A. (2007). History of Naga Anthropology: 1832-1947. Dimapur: Chumpo Museum.

29. Lotha, A. (2013). The raging mithun: Challenges of Naga nationalism. Barkweaver Publications.

30. McCosh, J. (1837). The Topography of Assam. Calcutta: Bengal Military Orphan Press.

31. McGuigan, J. (1992). Cultural populism. London and New York: Routledge.

32. McLuhan, M. (1964). Understanding Media: The Extensions of Man. New York: McGraw-Hill.

33. Mehta, N. (2008). India on television. Noida, New Delhi: HarperCollins Publishers.

34. Mills, J. P. (1922). The LhotaNagas. London: Macmillan.

35. Mills, J. P. (1926) TheAoNagas. London: Macmillan. 
36. Mills, J. P. (1937). The RengmaNagas. London: Macmillan.

37. Mills, J. P. (1988). The Effects on the Naga Tribes of Assam of Their Contact with Western Civilization. In J. Bodley (Ed.), Tribal Peoples and Development Issues: A Global Overview (pp.69-82). Mountain View, CA: Mayfield Publishing Co.

38. Pandey, S. K. (2011). Politics of belonging: Identity and State-formation in Nagaland. In J. Pfaff-Dzarnecka\& G. Toffin (Eds), The politics of belonging in the Himalayas(pp.98-121). New Delhi: Sage Publications,.

39. Pavarala, V. (1999). Studying Television Audiences: Problems and possibilities. Journal of Arts and Ideas, 32-33, 101-106.

40. Phanjoubam, P. (2015). The Northeast Question: Conflicts and Frontiers. Oxon and New York: Routledge.

41. Priya, S., \& Bhatiya, P. (2014). The Impact Of Unconventional Media On Rural Masses. Senior Lecturer \& Professor and Head, Department of MBA, Babu Banarsi Das National Institute of Technology and Management, Lucknow, 2(2), 23-32.

42. Ranganathan, M., \& Rodrigues, U. M. (2010). Indian Media in a Globalised World. New Delhi: Sage Publications.

43. Ravichandran, R., \& Varghese, D. J. Care for your students? Figure out their stress (correlating anxiety and communicationA peep Into the emotions of ESL learners).

44. Sema, P. (1992). British policy and administration in Nagaland 1881-1947. New Delhi: Scholar Publishing House.

45. Sen, A. (2011). Marginal on the map: Hidden wars and hidden media in Northeast India. Reuters Institute Fellowship Paper, University of Oxford.

46. Taylor, C. (1994). Multiculturalism: Examining the politics of recognition. New Jersey: Princeton University Press.

47. Thong, T. (2012). Civilized Colonisers and Barbaric Colonized: Reclaiming Naga Identity by Demythologizing Colonial Portraits. History and Anthropology23(3): 375-397. doi:10.1080/02757206.2012.697060.

48. Tufte, T. (2001). Minority Youth, Media Uses and Identity Struggle: the role of the media in the production of Locality. In K. Ross\& and P. Playdon (Eds.),Black Marks: Minority Ethnic audiences and media (pp. 33-48). Aldershot: Ashgate.

49. Venuh, N. (2004). Change of Political Institution of Naga Society. In N. Venuh (Ed.), Naga Society: Continuity and change (pp.93-97). Delhi: Shipra Publications.

50. Venuh, N. (2005). British Colonization and Restructuring of Naga Polity. New Delhi: Mittal Publications.

51. Weber, M. (1997). What Is An Ethnic Group?. In M. Guibernau\& J. Rex (Eds.), The Ethnicity Reader: Nationalism, Multiculturalism and Migration (pp.15-26). Cambridge: Polity Press.

52. Yonиo, A. (1974). The Risingnagas: A Historical and Political Study. Delhi: Vivek Publishing House. 